\title{
A public hearing as a form of the public participation in the urban planning
}

\author{
Olga Pavlycheva ${ }^{1, *}$ \\ ${ }^{1}$ Moscow State University of Civil Engineering, Yaroslavskoye sh. 26, Moscow, 129337, Russia
}

\begin{abstract}
Public hearings are a form of deliberal democracy and ensure the participation of people in the solving of social important issues. The article emphasizes the importance of public hearing, using in matters of the urban development; points out to the shortcomings of the main theoretical provisions, including the lack of a unified approach to understandofit.The importance of the institution of a public hearing and some its shortages, impeding the comprehension of this institution have been noticed in the article as well. In addition it is indicated the need of the unified system formation on the basis of the standard regulation of a public hearing to improve in the institution in law-enforcement practice.
\end{abstract}

\section{Introduction}

The Constitution of the Russian Federation 1993 fixes the most important peoples power in as the essential form

to express the democracy. A public hearing is one of the ways for the direct participation of people in the solving of problems at state and local level, including questionsin the urban planning's policy[1,2].

Essential feature of public hearings has a specific character in their legal nature.

First, public hearings are a form of deliberal democracy by its legalnature.Apublic hearing combines all elements of deliberative (dialogue) democracy (democracy discussions, consultative democracy) as a public social phenomenon combines elements of representative democracy (representatative democracy) direct democracy (direct democracy) and participatory democracy (participatory democracy)[3].

Secondly, they are represented by a complex legal institution, so its legal enforcement is discussed in the regulation of various branches of law, depending on what kind issues. So, for example, the organization and conduct of public harengs for the solution of land use's questions, building, territories' planning are not only in the sphere of interests the municipal, but also of agrarian right and the town-planning right.

Thirdly, as a public hearing is a kind of so-called deliberal (dialogue) democracy, a lot of questions must be considered in the context of the democracy principle, in state management and municipal authorities[4].

The adoption of resolution of a public hearing might include possibilities to reach compromise solutions.

*Corresponding author: olganik78@mail.ru 
In this regard the most important task of this work is to study the legal provision of public hearings as a form of democracy, to identify the main problems in the implementation of public hearings in the field of urban development.

\section{Methods}

The public hearing's institute is contained in the Federal law of 06.10.2003 № 131-FZ "On the general principles of the organization of local self-management in the Russian Federation" [2] as one of the forms of direct citizen's participation at the local level of management. In accordance with the legislative requirements many project acts such as the Statute of the municipality, plans and development programs, local budget, rules of land's use and development, land planning, and a number of other important issues concerning the municipality's life must be made through a public hearing. As a rule main concepts of public hearings are fixed in charter of municipal legal acts concerning the local value which is conducted by local government bodies according to the established procedure.

Public hearings in accordance with the law are a form of public control. In addition, the town-planning legislation requires that public hearings to be held on certain issues.

All this emphasizes the importance of public hearings as a legal institution and makes it necessary to study it.

In this paper, a comparative legal study was used to investigate public hearings. Both the norms of legislation and scientific works on the research topic, as well as judicial documents (documents of the Constitutional Court) were examined. The use of a comparative legal method made it possible to identify significant shortcomings and gaps in the legal provision of public hearings.

\section{Results}

Currently, many questions are being continued to remain at the federal level of goverment despite of importance the legal securing the conditions and grounds for the application of the Institute of public hearings in practice, both theoretical and applied nature.

We only note some problems.

The first problem is the lack of a unified approach to the understanding and of a public hearing nature.

In the legislation (Federal law of 21 July 2014 N 212-FZ "On bases of public control in Russian Federation "[5]) a public hearing is understood as the meeting of citizens organized by the subject of the public control and public authorities and local government bodies, state and municipal organizations, other bodies and the organizations which is conducted separate from public powers according to federal laws to discuss the questions concerning activity of the specified bodies and the organizations and having the special public importance or affecting the rights and freedoms of the person and the citizen, the right and legitimate interests of public associations and other non-state, non-profit organizations in the cases provided by the legislation of the Russian Federation.

In turn, the Constitutional Court of the Russian Federation also gives a description of the public hearing noting that "...as a public-legal institution designed to ensure an open, independent and free discussion of socially important problems (issues) that are essential for citizens living in the area of the public hearing, within the meaning of article 3 of the Constitution of the Russian Federation and Federal legislation, which governs their conduct, are not a form of exercise of the power by the population. Nevertheless, they give everyone who will be affected by the action proposed decision, the right authority to participate in the discussion independent of the existence of special knowledge or affiliation 
to certain organizations and associations. The ultimate goal of this discussion is to develop recommendations on socially public questions or to receive public evaluation of a legal act. Accordingly, the process of managerial decision-making has been becoming more open for citizens, and this openness is ensured by the coercive force of the law obliging the authorities to hold public hearings on certain issues..."[6].

Only a comprehensive analysis of the legislation, scientific literature and jurisprudence at the public hearing allows you to identify the signs of public hearings as a legal institute. These include the following:

- public hearings are designed to provide an open, independent and free discussion of socially important problems (issues). Compliance with these requirements allows us to provide resolution of a local issue timely and quality must be discussed [7];

- at the public hearings are discussed socially significant problems (questions) that are essential for citizens residing in public structure[7].

- free expression of opinion and condemnation of the questions having essential value for the population acts as the purpose of public hearings;

- equality of the parties of public hearings (public agents, on the one hand, and the population - with another);

- process of public hearings always is a topic of discussion, dialogue between the participants.

The second problem is a lack of systemacity and gaps in the federal legislation for public hearings which involves discrepancy of legal support of the legislation at the regional and local level, integrated locally. All of the above interferes with development of institute of public hearings.

Thus, in accordance with Articles 28,31,39 and 46 of the Urban Development Code, public hearings should be held on any public zone of the town and land etc. The projects and development rules, deciding whether to grant land use permits or providing a site for capital investment in the construction and getting a permit for deviation from the approved parameters of permitted construction, reconstruction of capital construction facilities, site planning and land management.

However, despite of the fact that the legislator makes a notes about the importance of public hearings as a way to express the power of the people, including the field of urban development. On the basic of acts the regulation of this institution is not enough at the federal level. Thus, in paragraph 2 of article 28 of the City Development Code, the organization and conduct of public hearings falls within the jurisdiction of local authorities[9]. At the same time there is no single requirments at the higher level regulation to the procedure of organization and conducting of public hearings, there is no requirement for mandatory consideration of public opinion expressed during the public hearings, and to the formulation of a final decision on the issue submitted to a public hearing.

This is a significant omission, because the lack of a uniform approach to the implementation of public hearings causes a number of problems arising to the implementation of the legal institute. Among the more often some problems include things such as ignoring public opinion, abuse in the course of public hearings. Thus, the population has no opportunities to exercise their rights[10].

\section{Discussion}

Among the most urgent problems the legal regulation of the Institute of public hearings include the following:

1. Now a unified approach to a conceptual framework of institute of public hearings, definition of their place and a role in system of providing basic principles of democracy in the state has not been created. Adequately the essence of institute of public hearings has not 
been investigated, the maintenance of the concept "public hearings", their subject have not been worked out, the mechanism of their realization has insufficiently not been investigated [11].

The decision of this problem is in the conducting of theoretical researches and fixing thear results as uniform approaches to the public hearings in the legislation. Besides that public harengs features, definition of the places where they take among other constitutional and legal institutes, development of their mechanism and the identification the main stages of their realization must be reflected in the legislation too. All this will help to avoid the negative consequences caused by various understanding and interpretation of this legal institute.

2. The fundamental purpose of conducting of public hearings has not been defined at all. So, in particular, in article 28 of Urban Development Code only some objectives of public hearings had not been reflected in the sphere of town planning, namely: ensuring compliance with human right on favorable conditions for activity; ensuring rights and legitimate interests of owners of the land plots and capital construction projects.

3. The fundamental purpose of the organization and conducting of public hearings is coordination of interests of the state and a society with interests of individuals. Unfortunately, the legislator did not reproduce the principle of coordination of the state and public concerning the field of town-planning activity from the former Urban Development Code of the Russian Federationin the town-planning activity[12].

In turn, we can traced the insufficient understanding of the legal nature, no understanding purpose and awareness of the importance of institute of public hearings among the population. That is why the main cause is lack of people's interest in public hearings and the result is not attracting to take part in it.

Thus the population loses an opportunity to participate in management in the territory where they live.

4. There is no uniform in the standard and no legal base for providing institute of public hearings at the federal level. Now that issue is resolved by public authorities of subjects and local government bodies independently.

Such approach causes serious complaints as it leads to the unsystematic character and will cause some difficulties in the practical activity.

5. Currently the results of public hearings are only recommendatory, but may not be binding by character. It leads to the fact that decision-making may be contrary to will of the population, leads to loss of legitimacy of the power, a lack of supporting by the population, its unwillingness to cooperate with the power, to decrease in investment activity and other manifestations of mistrust[13].

To find a wayout the solution of this problem is necessary to enshrine some certain conditions where are the result of public hearings will have a fundamental value to solve questions according to which public hearings are conductedby.

It must be necessary to introduce a certain quorum at which public hearings will be declared valid, and percent of the given votes at which achievement the result of hearings will be a basis for acceptance of the final decision.

6. Now by the legislation it is not provided accurate regulations of the procedure of conductpublic hearings. So, the town-planning legislation, fixing obligation of conductpublic hearings on a number of questions, does not contain requirements to the procedure of the organization and carrying out public hearings, does not define structure and structure of the bodies authorized for conduct public hearings, to structure and an order of preparation of documentation, the accounting of opinion of the population stated at hearings etc.

It is necessary, not only to legislate clear and detailed regulation of the procedure of organization and holding of public hearings, with specific stages, their timing and content, 
but also to establish requirements to the procedure of informing of the population about upcoming hearings, time, about the venue and the issues to be submitted to public hearings, but also the procedure of informing the population about the results of public hearings and their importance for the final decision.

\section{Conclusions}

The paper presents only a little part of the problems associated with the Institute for public hearings. However, to reduce the number of problems at the legal level significantlyis only possible by a special Federal law "About public hearings", which would enshrine the fundamental concepts of public hearings, the order of organizing and conducting in Russia, as well as responsibility for violations of public hearings legislation.

The law should have provided a framework and become the fundamental normative act in this sphere. The structure of this law should include two parts: General and Special.

The law should have reflected:

- concepts, goals, objectives of public hearings;

- rights, duties and responsibilities of participants;

- stages, terms and the order of their maintenance;

- results of taking into account the interests of public listeners and other aspects related to the Institute as a whole, irrespective of the field of activity.

In addition, the need to separate the sections of a normative act, to reflect the characteristics of the public hearings of certain types taking into account the specifics of industry characteristics (for example, in the field of construction, budget, management activities, etc.)

It is also necessary to develop and consolidate in the appendix to this law the regulations of forms in the documents relating to the organization, maintenance and registration of the results of public hearings. This will greatly simplify the procedural aspects of public hearings and make them more general and uniform.

\section{References}

1. Z.I.Ivanova, A.D.Ishkov, N.G.Miloradova,Sociological and psychological methods for sustainable development of a city (Celebrating Project Successes, 2015)

2. Russian Federal law of 06.10.2003 № 131-FZ

3. D.W.Johnson, Journal of Peace Psychology 6(4), 84-95(2000)

4. N.G.Miloradova, A.D. Ishkov, Procedia Engineering 117, 246-251 (2015)

5. Federal law of 21.07.2014 N 212-FZ

6. P.M. Ivashkova, Molodoj uchenyj10(3), 14-16 (2016)

7. Urban Development Code of the Russian Federation from 29.12.2004 N 190-FZ.

8. I.P.Pryadko, International Journal of Applied Engineering Research 21, 42147 (2015)

9. Z.I. Ivanova, Journal of Economy and entrepreneurship10(8), 563-566(2016)

10. S.A.Burmistrova,Vestnik JuUrGU3, 59-61(2013)

11. M.D. Safarova, Imushhestvennye otnoshenija v Rossijskoj Federacii9,10 (2015)

12. S.A. Krymov, Voprosy imushhestvennoj politiki 7(142), 45(2013) 